кандидат історичних наук, доцент кафедри всесвітньої історії, докторант Дрогобицького

державного педагогічного університету імені Івана Франка

(Україна, Дрогобич) galykvol@ukr.net

\title{
ДРОГОБИЧ ТА ЙОГО ОКОЛИЦІ В ХУДОЖНЬО-ЛІТЕРАТУРНІЙ СПАДЩИНІ ІВАНА ФРАНКА
}

У запропонованій статті окреслено та проаналізувано художньо-літературну спадщину Івана Франка, де прямо чи сюжетно представлене місто Дрогобич. Акцентовано, щзо упродовж усього свого життя Іван Франко приділяв значну увагу опису краєвидів Дрогобича та його околиць у свойх художньо-літературних творах. Сюжети, які подані у полишеній Франковій спадщині торкаються проблем сьоціально-економічного, політичного та культурного розвитку Дрогобича, життя й побуту дрогобичан (українців, поляків, євреїв) і йнших різного роду проблем, якими тяготіло місто у другій половині XIX - на початку ХХ століття. Визначено, щзо письменникові належить близько тридчяти такого роду творів, у яких різноаспектно показане минуле міста Дрогобича Франкового часу.

Ключові слова: Іван Франко, Дрогобич, околиці, художньо-літературна спадщина, твори малої прози, поетичні твори, сюжетна канва.

Лim. 36.

Volodymyr HALYK,

PhD (History), Assistant Professor of World History, Doctoral Departament of Drohobych Ivan Franko State Pedagogical University (Ukraine,Drohobych)galykvol@ukr.net

\section{DROHOBYCH AND ITS OUTSKIRTS IN LITERATURE HERITAGE OF IVAN FRANKO'S}

In the suggested article we define and analyse Ivan Franko's literary heritage where the town of Drohobych is direcly represented. We emphasize that dring his life time Ivan Franko pays particular attention to the description of the views of Drohobych and its outskirts in his literary works. The plots, represented in Franko's heritage, touch upon the problems of social, economic, political and cultral development of Drohobych, the life of Drohobychers (Ukrainians, Poles, Jews) and other different problems which existed in the town in the second half of the 19th and at the beginning of the 20th centuries. For example, such poems as «Pokhvala Drohobycha» ( "The Praise of Drohobych»), "Drohobytska Philantropiya» ("Drohobych Philanthropy») in the satirical style ridicule the social economic state in the town at the times of Ivan Franko, and his poetic work "Ukrainian-Ruthenian student summer trip in 1884» became the so-called description programme of its participants' actions which started from Drohobych saltworks factory. In his verse poem «Vandrivka Rusyna $z$ Bidoyu» ("A Ruthenian's Trip with Grief») Ivan Franko gives the description of Galician cities and towns including Drohobych where in the context he tells about the misery and hard life of the local people. The plots of Drohobych life at Ivan Franko's times, town's streets and outskirts is the canvas of numerous works of the writer's small prose: "Pyrohy z chernytsyamy» («Blackberry pies»), «Perekhresni stezhky» ("Cross Paths»), «Boryslav smiyetsya» ("Boryslav laughs»), «Boa constrictor» and others. Such stories as "Gava», "Dobryi zarobok» ("A Good Earning»), «Zlisnyi Sydir» («Angry Sydir», «Batkivshchyna» («Motherland»), «Velykyi shum» ("Big Noise») etc. belong to the number of Franko's works where the town Drohobych is represented. In general, we define that the writer owns nearly thirty works of this kind in which he shows the past of Drohobych of Franko's times.

Key words: Ivan Franko, Drohobych, outskirts, literary heritage, works of small prose, poetic works, plot canvas.

Ref. 36. 
Владимир ГАЛЫК, кандидат исторических наук, доиент кафедры всемирной истории, докторант Дрогобычского государстенного педагогического университета имени Ивана Франко (Украина, Дрогобыч) galykvol@ukr.net

\title{
ДРОГОБЫЧ И ЕГО ОКРЕСТНОСТИ В ХУДОЖЕСТВЕННО-ЛИТЕРАТУРНОМ НАСЛЕДИЕ ИВАНА ФРАНКО
}

\begin{abstract}
В предлагаемой статье обозначено и проанализувано художественно-литературное наследие Ивана Франко, где прямо или сюжетно представлен город Дрогобыч. Акиентировано, что на протяжении всей своей жизни Иван Франко уделял значительное внимание описанию видов Дрогобыча и его окрестностей в своих художественно-литературных произведениях. Сюжеты, которые представлены в оставленном наследии Ивана Франко, касаются проблем сьоциально-экономического, политического и культурного развития Дрогобыча, жизни и быта дрогобычан (украинцов, поляков, евреев) и других разного рода проблем, которые переживал город во второй половине XIX - начале XX века. Определено, что писателю принадлежит около тридиати такого рода произведений, в которых разноаспектно показано прошлое города Дрогобыча времени Ивана Франко.
\end{abstract}

Ключевые слова: Иван Франко, Дрогобыч, окрестности, художественно-литературное наследие, произведения малой прозы, поэтические произведения, сюжетная канва.

Лит. 36.

Постановка проблеми. Вікодавнє місто Дрогобич посідає чільне місце у багатогранній творчій спадщині Івана Франка. І це не дивно, адже тут він навчався у Дрогобицькій головній школі при церкві Святої Трійці, Дрогобицькій вищій гімназії імені Франца-Йосифа. Із Дрогобича разом із групою товаришів-однодумців I. Франко розпочинав свою славнозвісну культурно-просвітну «прогулянку» Прикарпаттям. Яскравовиражену присутність Дрогобича можна побачити як у Франкових історико-краєзнавчих, етнографічно-фольклорних працях [див. напр.: $1 ; 8]$, так і в численних художньо-літературних творах. 3 огляду на це, акутуальним, на наш погляд, вбачається саме аналіз художньо-літературної спадщини Івана Франка, де представлено Дрогобич як головний чи другорядний персонаж.

Аналіз досліджень. Порушена нами тема у франкознавсті, а особливо у літературознавчому не нова. Чимало дослідників різноаспектно аналізували художньо-літературну спадщину Івана Франка, проте історико-краєзнавчих праць на сьогодні є небагато. В цьому плані хочемо назвати таких дослідників-франкознавців, як 3. Гузар [6], Я. Грицак [5], Р. Мних [7], Р. Горак та Я. Гнатів [2; 3; 4], які сюжетно торкалися аналізу окремих художньо-літературних творів Івана Франка, де присутня тема Дрогобича.

Мета статті - максимально повно окреслити художньо-літературні праці Івана Франка, де присутня дрогобицька тематика.

Виклад основного матеріалу. Сюжети про Дрогобич та його околиці присутні у низці віршованих творів письменника, а це - «Похвала Дрогобича», "Дрогобиџька філантропія», «Украйнсько-руська студентська мандрівка літом 1884 р.», «Вандрівка Русина з Бідою». Перші два вірші - «Похвала Дрогобича» [29], «Дрогобицька філантропія» [21] - у сатиричному стилі висміюють соціально-економічне становище Дрогобича у добу Івана Франка. «Украӥнсько-руська студентська мандрівка літом 1884 р.» [35] слугувала віршованим описом-програмою дій їі учасників, яку було розпочато саме із теренів дрогобицької солевиварювальної жупи.

У віршованій поемі «Вандрівка Русина з Бідою», написаній упродовж 20 березня 13 квітня 1893 р., І. Франко, мабуть, частково і у своєму прообразі та інших героїв подає опис подорожі містами й містечками Галичини, в тому числі Дрогобичем, де в контексті розповідає про злидні і нелегке життя місцевого населення, різнобарвну діяльність непересічних постатей краю, про різні події, пригоди тощо. Ось як зображений Дрогобич у цьому творі: «Приїхали у Дрогобич. / «Отут, Бідо, щзо нам зробиш? / Русин послом, бурмістром, / Гімназії міністром!» / Каже Біда: «Лиш помалу! / Доберу я причандалу: / Тут доносів, там виния, / Та й доїду їм 
кіния!» / 3 Дрогобича у Борислав / Русин Біду саму вислав. / «Іди, Бідо, не гайся, /Здоровенька вертайся!» $[14,132]$.

Тема соціально-економічного життя Дрогобича присутня у драмі I. Франка «Украдене щастя». Зокрема, головний герой Микола Задорожний їздив із Незванич (прообраз села Нагуєвичі) до дрогобицької солевиварні за дровами [див.: 34]. Наперед зазначимо, що дрогобицька солевиварня фігурує і в змісті Франкового твору «Boa Constrictor» [див.: 10].

Побіжно зауважимо, що дрогобицька соляна ропа сюжетно присутня і в низці інших творів Івана Франка. Наприклад, у праці «Жіноча неволя в руських піснях народних» автор описав, як карали дівчат, «котрі дали волю нерозважливій любові» [див.: 23]. За його словами: «...̈̈х ждала ганьба перед иілою громадою, декуди на зарінку за иеекквою або коло корчми били їх прилюдно шнурами від дзвонів, котрі перед тим на кілька день намочені були в соляній ропі (Дрогобич)» $[23,218]$. Зі слів письменника видно, що вкрай важким у його час було становище жінки, а особливо тоді, коли вона мала за своїми плечима значні гріхи. В контексті цього скажемо, що в згаданій праці присутній ще один сюжет про долю жінок-дрогобичанок, які мали нещасливе кохання. 3 цього приводу I. Франко пише: «Але не тільки з нелюбим чоловіком лихо жити жіниі. Не краща доля чекає ї̈ звичайно $і$ за тим, котрого вона дівчиною полюбила. Се видно з многих пісень, як, напр., з сеї: Ти, зелена лішинонько, / Чому гилля й опускаєш? / Ти, молода молодице, / Чому сльози проливаєш? / Ой, я гилля й опускаю, / Тугу зиму прочуваю; / Ой я сльози проливаю, / Бо лихого мужа маю. / Ой не казав мені й отець, / Не казала мені мати, / Сама-м біду полюбила, / Ні на кого нарікати. (Дрогобич)» [23, 231].

Сюжети дрогобицького життя часу I. Франка, міські вулиці та околиці є канвою багатьох творів малої прози письменника. Колорит вулиці Панської (згодом А. Міцкевича, а тепер Т. Шевченка) простежений в оповіданні «Пироги з черницями» [див.: 28].

Чимало місця відведено Дрогобичу у повісті «Перехресні стежки» [див.: 27]. Тут автор описує дрогобицький малий і великий ринок, міський парк відпочинку, ратушу з годинником, костел і сквер навколо нього, міст, вживає такі топоніми, як Клекіт, Вигода тощо. Для прикладу наведемо кілька уривків, щоб побачити, як I. Франко змальовує Дрогобич з його околицями: «... Гарне помешкання, поверховий дім, фронт на вулиџю, довкола сад, а затильні вікна виходять на міський парк. Чудесне положення при головній вулиці, недалеко ринку і недалеко руської церкви...» $[27,184]$; «...Ринок $і$ вулиця, щุо вела до иеркви, були повні святочно поприбираних міман $i$ передміщан. Дзвони гули і грали в повітрі. Сонце сипало золотим, ще не дуже палким промінням із безхмарного неба. Від ріки, щзо широким луком обгинала місто з двох боків, тягло вогким холодом. Було чудово гарно, весело, привітно довкола,...» $[27,186] ;$ «...Він зупинився. Вона щезла, а він звільна пішов у противний бік, довго блудив по різних площах $і$ заулках, поки вийшов на ринок, і потім ніяк не міг пригадати собі, де се було, де вона покинула його і де ії помешкання...» [27, 240]; «На годиннику вибила одинадията. Найближчі вулиці, облиті місячним світлом, були пусті. Де-де на розі вулиці блимала жовтавим світлом лампа. Де-де в шинках світилися вікна, і відтам лунали крики та співи; далеко по передмістях переливалися голоси померзлих колядників...» $[27,352]$; «...В його голові засіла думка, щзо мусить, отак тарабанячи, обійти три рази довкола ринок, потім обійти костел, пройти здовж головну вулицю, а потім боковою вулицею вернути додому...» [27, 353]; "...Якраз в тій хвилі виглянув місяџь із хмари і показав його очам контури високого будинку з кінчастими вежами і золотими хрестами. Се був костел...» [27, 356].

Не оминув I. Франко Дрогобича у повісті «Борислав сміється» [див.: 13]. В основу твору покладено закладини і будівництво будинка Леона Гартенберга, знаного та успішного підприємця. Згаданий дім у всій своїй красі існує до сьогодні. Повість починається зі слів: «Сонще досягало вже полудня. Годинник на ратушевій вежі в вибив швидко і плачливо одинадияту годину. Від громадки веселих, гарно повбираних панів-обивателів дрогобицьких, щзо проходжувалися по плантах коло костела в тіні иввітучих каштанів, відділився пан будовничий $і$, вимахуючи блискучою паличкою, перейшов через улицю до робітників, занятих при новорозпочатій будові» $[13,256]$.

Загалом сюжетну канву Франкового твору «Борислав сміється» наповнюють краєвиди Стрийського (показано стрийський «гостинець»), Бориславського (показано бориславську 
вулицю), Стебницького (на ньому пройшла сутичка між селянами та дрібними підприємцями за право поставок будівельного матеріалу на будову будинку Леона Гартенберга) та Самбірського (самбірський «гостинець») трактів, тобто усі найважливіші сполучні шляхи міста Дрогобича 3 іншими містами [див.: 13, 256-480]. Побіжно скажемо, що більш детально Бориславський трактат у Дрогобичі Іван Франко описав у своїх мемуарах «У столярні» [див.: 33, 171-189].

Крім того, у повісті змальоване соціально-економічне становище населення Дрогобича, наводяться паралелі статків та побуту бідних і багатих верств, окреслено особливості соціальних відносин тощо. Ось, для прикладу, подаємо уривки, які відображають соціальний склад міста, особливості життя та побуту дрогобичан Франкового часу: «...Робітники, щуо стояли над ямою, чекаючи на розказ майстра, зависно гляділи на цілий той обряд. Но ось уже кидання грошей скінчилось - ямка мало щзо не повна. Леон, щчо досі стояв при східиях і всіх виходячих з ями приязно стискав за руки (з Германом та з шляхтичем він на радощах навіть поцілувався), тепер виступив наперед $і$ казав принести плиту та иемент, замурувати фундамент...» [13, 266]; «...Минуло вже три неділі від закладин. Леонів дім швидко здвигався догори: підвалини були вже положені, і фронтова стіна з тесаного каміння зносилася вже на лікоть понад землею. Будовничий наглядав за роботою, а в перших днях і сам Леон иілими днями тут просиджував, нипаючи в кождий кут і всіх понукуючи до поспіху. Але се недовго тривало. Якесь нагле діло покликало Леона до Відня, а хоть без нього робота й не йшла повільніше, то прецінь робітники якось легше відотхнули, не видячи над собою тої вічної змори...» $[13,296] ;$ «Була неділя, коли Бенедьо вибрався в дорогу. В иееккі святої Трійці, попри котру переходив, дяки гриміли хвалу божу. А напротив иеркви, на нужденнім дрогобицькім бруку, попід муром, сиділи купами ріпники в просяклих нафтою сорочках та подертих кахтанах, ждучи, аж скінчиться хвала божа, щьоб відтак рушити до Борислава. Деякі хрестилися та шептали «отченаші», другі дрімали на сонячній спеці, інші знов держали в руках десятикрейцарові хлібенята $і$ ичибулю $i$ їли, кусаючи з иілого, некраяного хліба. Бенедьо не задержувався коло иеркви, не дожидавсь кіния хвали божої... Але немало здивувався Бенедьо, коли, вийшовши за місто, побачив, щэо як далеко тяглася дорога, всюди по ній мріли купки ріпників, звільна поступаючи серед туманів пороху. Ті не ждали кінця хвали божої, а спішать, щоб залучити деяку роботу. Хліб видно у кождого в брудній полотняній торбі; у деяких з торби висувалися зелені пера молодої ичибулі...» $[13,302-303]$.

Чимала сюжетна лінія про Дрогобич преставлена у Франковій повісті «Boa constrictor» [див.: 10, 370-443]. Центральним персонажем твору виступає успішний підприємець, власник нафтопромислу у Бориславі Герман Гольдкремер. Із початку повісті стає видно, що він проживає в Дрогобичі, має великий будинок, водночас показано періодичність його проживання у місті: «Герман Гольдкремер встав нині дуже злий. Він все такий, кілько разів йому лучається ночувати в Бориславі. А лучається то щотижня раз, в n'ятницю, коли приїздить сюди з Дрогобича оглянути роботу і виплатити ріпникам. Герман Гольдкремер, хоть маєток його доходить до мільйона, ніколи не звірює чужим очам надзору ані чужим рукам виплати...» [10, 370].

У повісті «Boa constrictor» приділено увагу описові колориту єврейського кварталу у Дрогобичі - Лан, де саме проживав головний персонаж: «...I досі він живо нагадує тоту напіврозвалену, підгнилу, вогку, нехарну $і$ занедбану хатку на Лану в Дрогобичі, в котрій побачив світ. Стояла вона над самим потоком, напротив старої і ще відразливімої гарбарні, відки щзотижня два трудоваті каправоокі робітники виносили ношіями спотребований і переквашений луб, котрий на всю пересторону (перію) ширив кислий, удушливий, убиваючий сопух. Побіч хати його матері стояло багато других, подібних. Всі були скопичені так густо, дах у кождої був такий нерівний, перегнилий та пошарпаний, щуо ичіла тота пересторона подобала радше на одну нужденну руїну, на одну велику купу сміття, плюгавства, гнилого дилиння та шмаття, як на людське житло...» [10, 373].

Водночас, у повісті I. Франко акцентував на наслідках холери літа 1831 р., яка пройшлася Дрогобиччиною і полишила після себе немалу кількість смертей. Стосовно іiї впливу на Дрогобич автор зазначив: «I Дрогобича не минула холера. Особливо Лан утерпів від неї більще, як другі передмістя, чи то тому, щзо тут затхлий та нечистий воздух помагав ширенню зарази, 
чи, може, тому, щзо люди, стіснені густо в одних хатах, легко одні від других заражувалися. Жиди, жидівки, а найбільше малі діти падали, мов трава під косою, умирали серед глуші, тихо потайно, по кутах та закамарках...» $[10,376]$.

Продовжуючи розповідь про життєвий шлях головного героя, I. Франко змальовує колорит околиць Дрогобича, зокрема акцентує на горі Тептюж, через яку сам неодноразово ходив навпростець до Борислава, а також згадує і про чи не головну водну артерію, яка тече через усю південно-східну частину міста - річку Тисменицю. Ось як І. Франко представив художній образ Тептюжа і Тисмениці: «...Вони ішли через Тептюж, лишаючи Губичі збоку. Сонце сходило над Дрогобичем і облило кровавим світлом ратуш, костел $і$ ичерков святої Тройці. Сюди ближче вилася, блискотячи, мов золота змія, Тисьмениця і шваркотіла в віддалі по камінні. Дуби в Тептюжі іно щзо зачинали розвиватися, зато сподом ліщина шевеліла вже свойм широким темно-зеленим листям...» [10, 393].

Водночас, акцентуємо на тому, що гору Тептюж, ліс Гірку та річку Тисменицю письменник загадав у передмові до оповідання «Рутениі», де ділиться спогадами про своє дозвілля у роки навчання в Дрогобицькій гімназії. Зокрема, I. Франко пише: «Маючи від дитинства замилування до збирання грибів у лісах та до ловлення риб у річках та потоках, я також із Дрогобича в неділі та свята, або коли був вільний час, то й серед тижня, при погоді ходив чи то сам, чи з товаришами в околичі міста, до лісу, званого Гіркою, до другого, званого Тептюж, зложеного з самих дубів, а також до ріки Тисьмениці, що пливе з південного боку міста Дрогобича, в якій ученики в різних місиях купалися...» [30,9]. Дещо подібні враження від відвідування вищеокреслених околиць міста та його водної артерії І. Франко представив у «Споминах із моїх гімназіальних часів» $[32,50-54]$.

Темою Дрогобича просякнуті й інші твори малої прози письменника. Уже згадувані новела «На дні» [25, 110-163] та спогад «Як ие сталося?» [36, 372-376] змістовно охоплюють час перебування I. Франка у дрогобицькій в’язниці під час арешту у 1880 р. Найповніший та найвідоміший опис Дрогобича вміщений автором у вже згадуваних спогадах «Гірчичне зерно», де демонструється ось яка картина міста: «В часі мойх гімназіяльних студій Дрогобич був містом, дуже багатим на нетативні прикмети. Почислити, чого там не було, - вийде дуже довгий реєстр. Не було ані одної порядної кав'ярні, ані реставрації, ані одної публічної бібліотеки, ані одного освітнього товариства, ані одного зібрання чи то з політичною, чи з освітньою метою. Не було майже нічого того, щзо характеризує хоч наполовину европейське місто. Не було навіть води, крім домашньої соленої, якої посторонні люди не могли пити. Більшість вулиць без тротуарів та без освітлення, а широко розкинені передмістя, особливо Задвірне, Завізне та Війтівська Гора, були собі прості села з солом'яними стріхами, огороджені плотами, з захованням зовсім сільського характеру. Залізницю з Дрогобича до Стрия побудувано, коли я був у сьомім гімназіяльнім; до того часу Дрогобич був собі «вільним королівським містом», вільним, невважаючи на свою нормальну школу та гімназію, від усього, щуо пахло цииілізацією та інтенсивнішим духовим життям» [17, 316].

До творів І. Франка, у яких представлене місто Дрогобич, потрібно долучити такі, як: «Гава», «Добрий заробок», «Злісний Сидір», «Батьківщина», «Великий шум». Перші три оповідання за сюжетом різні, але в них усіх розповідається про дрогобицький ринок. Наприклад, в оповіданні «Гава» події розгортаються у коловороті підприємницької діяльності головного героя на ринку міста Дрогобич [16, 7-31]. Дрогобицький ринок та способи заробітку на ньому сільських убогих людей із навколишніх сіл відображено у Франковому творі «Добрий заробок» [20, 230-235]. У незакінченому оповіданні «Злісний Сидір» автор описує повсякденний побут на дрогобицькому ринку: «...Цілий дрогобицький ринок повний був народу. Голота була страшенна. Тиснулись, кричали на різні лади, перекликувались, сварились та побратимались, а все серед безконечної хмари пороху, що здвигався понад ринком, мов густа сіра хмара...» [24, 442].

Дещо іншими за сюжетною канвою $є$ два інші твори малої прози Івана Франка. В оповіданні «Батьківщина», яке назване на честь головного героя, котрого прозвали Батьківщиною за те, що всіх рідних називав, перекручуючи: батька - «батьківщиною», матір - «материзною», стрика - «стрийщиною» і так далі, одним словом, був веселим хлопцем, - схарактери- 
зовано здібності головного персонажа. Автор підкреслює, що він: «...був незвичайний майстер від язика. Він один у цілій намій гімназї̈ вмів не тільки говорити по-бойківськи, бойківськими словами, формами й акиентом, але знав характерні нюанси говору майже кождого села в околиці Дрогобича» $[12,391]$. Загалом окреслене оповідання - це свого роду художньозабарвлена розповідь про життя та долю одного із дрогобицьких гімназистів, який, очевидно, міг мати приятельські відносини з автором цитованого тексту.

Другий твір I. Франка, повість «Великий шум», також містить сюжетну канву, яка розгортається у Дрогобичі. Автор пише: «Тай ті два любили ромовляти з Яцем, щзо хоть сам не письменний, а все таки не лише термінував три роки в Дрогобичі у славного Коваля $i$ довголїтнього иехмістра Мороза, але й потім у часї тїсних років часто їздв на Поділє по пшеницю та до Садагури по кукурузу, яку дома розпродував, та возив сіль із Дрогобича у ті подільські й покутські сторони, де люде, як він мовляв, дуже лакомі на тоту сьвяту сіль, бо iï y себе не мають...» $[15,221]$. На наш погляд, герої, які представлені у цитованих рядках, виступають праобразами Якова Франка та Михайла Мороза, адже саме батько письменника здобував ази ковальської справи у знаного дрогобицького коваля. В останніх частинах повісті описано судовий процес над Костем Дум'яком, який відбувався у дрогобицькій судовій залі міста [див.: 15, 208-317].

Висновки. Підсумовуючи, скажемо, що $є$ ще низка Франкових літературних та літературно-критичних праць, у змісті яких, у контексті, згадується Дрогобич, а це - «Останки первісного світогляду в руських і польських загадках народних» (згадка про зміст дражнилівки, яка побутувала у Дрогобичі) [див.: 26]; «Przyczynek do etnografii ludu ruskiego na Wotyniu» (згадка факту існування в Дрогобичі легенди про перетворення людини на лелеку) [див.: 11]; «Сожжение упырей в с. Нагуевичах в 1831 г.» (згадується розповідь про існування «червоного упиря» у дрогобицькому монастирі) [див.: 31]; «Дальші болгарські пращі М. Драгоманова» (згадується дрогобицька легенда про попа-злодія і як він став перевертнем) [див.: 18]; «Жидівська війна. Причинок до порівняльних студій над народною літературою» (згадується повчальна розповідь, яка побутувала в Дрогобичі про сліпого діда та хлопця-провідника) [див.: 22]; «Угорська казка» Вайлава Потоиького $i$ «пся крев» (згадується анекдот, записаний у Дрогобичі, про сліпого русина) [див.: 9]; «До питання про перекази про Магомета у слов'ян» (згадується польське прислів'я: «Якщо не йде гора до Магомета, то Магомет йде до гори», почуте в Дрогобичі від отця-катехита василіянського чину) [див.: 19].

Отже, уся художньо-літературна спадщина I. Франка, у якій він повністю чи бодай мазком зачепив тему Дрогобича, за нашими підрахунками, складає біля трьох десятків праць, а це поетичні, художньо-літературні, літературно-критичні тощо.

\section{СПИСОК ВИКОРИСТАНОЇ ЛІТЕРАТУРИ}

1. Галик В. Дрогобич в етнографічно-фольклорній спадщині Івана Франка / В. Галик // Розвиток сучасної освіти і науки: результати, проблеми, перспективи. Тези II-ї міжнародної науково-практичної конференції молодих вчених (Дрогобицький державний педагогічний університет імені Івана Франка, 25 квітня 2014 року) / Редактори-упорядники: В. Ільницький, А. Душний, І. Зимомря. - Дрогобич: Посвіт, 2014. - C. 49-51.

2. Горак Р. Адреси юності Івана Франка в Дрогобичі / Р. Горак. - Трускавець: «Франкова криниця», $1995-16$ c.

3. Горак Р. Іван Франко / Кн. друга. Цілком нормальна школа / Р. Горак, Я. Гнатів. - Львів: Видавництво отців Василіян «Місіонер», 2001. - 204 с.

4. Горак Р. Іван Франко / Кн. третя. Гімназія / Р. Горак, Я. Гнатів. - Львів: Видавництво отців Василіян «Місіонер», 2001. - 360 с.

5. Грицак Я. Пророк у своїй вітчизні. Франко та його спільнота $(1856-1886)$ / Я. Грицак. - К.: Критика, 2006. -632 с.

6. Гузар 3. Місто Івана Франка - Дрогобич / 3. Гузар. - Дрогобич: видавець Сурма С., 2008. - 192 с.

7. Мних Р. «Дрогобич, Дрогобич...» топос Дрогобича у творах I. Франка та Бруно Шульца [фрагмент образу Дрогобича у творах Франка] / Р. Мних // Франкознавчі студії. - Дрогобич, 2005. - С. $64-73$.

8. «Там город преславний Дрогобич лежить...» (Вибрані праці Івана Франка про Дрогобич) / Упорядкування, передмова і коментарі Володимира Галика. - Дрогобич: Коло, 2008. - 200 с. 
9. Франко I. «Угорська казка» Вацлава Потоцького і «пся крев» / I. Франко // Франко І. Зібрання творів у 50-ти т. + додаткові томи. - Т. 28. - К.: Наукова думка, 1980. - С. 305-318.

10. Франко I. Boa constrictor / I. Франко // Зібрання творів у 50-ти т. + додаткові томи. - Т. 14. - К.: Наукова думка, 1978. - С. 370-443.

11. Франко I. Przyczynek do etnografii ludu ruskiego na Wołyniu / I. Франко // Франко I. Зібрання творів у 50-ти т. + додаткові томи. - Т. 27. - К.: Наукова думка, 1980. - С. 210-215.

12. Франко I. Батьківщина / I. Франко // Франко I. Зібрання творів у 50-ти т. + додаткові томи. Т. 21. - К.: Наукова думка, 1979. - С. 391-423.

13. Франко I. Борислав сміється / І. Франко // Франко І. Зібрання творів у 50-ти т. + додаткові томи. Т. 15. - К.: Наукова думка, 1978. - С. 256-480.

14. Франко I. Вандрівка Русина з Бідою / I. Франко // Франко I. Зібрання творів у 50-ти т. + додаткові томи. - К.: Наукова думка, 1979. - Т. 1. - С. 126-141.

15. Франко I. Великий шум / I. Франко // Франко I. Зібрання творів у 50-ти т. + додаткові томи. Т. 22. - К.: Наукова думка, 1979. - С. 208-317.

16. Франко І. Гава / І. Франко // Франко І. Зібрання творів у 50-ти т. + додаткові томи. - Т. 18. - К.: Наукова думка, 1978. - С. 7-31.

17. Франко І. Гірчичне зерно (Із моїх споминів) / І. Франко // Франко I. Зібрання творів у 50-ти т. + додаткові томи. - К.: Наукова думка, 1979. - Т. 21. - С. 316-332.

18. Франко I. Дальші болгарські праці М. Драгоманова / I. Франко // Франко I. Зібрання творів у 50-ти т. + додаткові томи. - Т. 28. - К.: Наукова думка, 1980. - С. 293-298.

19. Франко I. До питання про перекази про Магомета у слов’ян / I. Франко // Франко I. Зібрання творів у 50-ти т. + додаткові томи. - Т. 29. - К.: Наукова думка, 1981. - С. 122-148.

20. Франко I. Добрий заробок / I. Франко // Франко І. Зібрання творів у 50-ти т. + додаткові томи. Т. 15. - К.: Наукова думка, 1978. - С. 230-235.

21. Франко I. Дрогобицька філантропія / I. Франко // Франко I. Зібрання творів у 50-ти т. + додаткові томи. - Т. 3. - К.: Наукова думка, 1976. - С. 248-249.

22. Франко I. Жидівська війна. Причинок до порівняльних студій над народною літературою / I. Франко // Франко І. Зібрання творів у 50-ти т. + додаткові томи. - Т. 53. - К.: Наукова думка, 2008. C. 311-330.

23. Франко I. Жіноча неволя в руських піснях народних / I. Франко // Франко І. Зібрання творів у 50-ти т. + додаткові томи. - Т. 26. - К.: Наукова думка, 1980. - С. 210-253.

24. Франко I. Злісний Сидір / I. Франко // Франко I. Зібрання творів у 50-ти т. + додаткові томи. Т. 16. - К.: Наукова думка, 1978. - С. 433-446.

25. Франко I. На дні / І. Франко // Зібрання творів у 50-ти т. + додаткові томи. - Т. 15. - К.: Наукова думка, 1978. - С. 110-163.

26. Франко І. Останки первісного світогляду в руських і польських загадках народних / I. Франко // Франко І. Зібрання творів у 50-ти т. + додаткові томи. - Т. 26. - К.: Наукова думка, 1980. - С. $332-346$.

27. Франко I. Перехресні стежки / I. Франко // Франко I. Зібрання творів у 50-ти т. + додаткові томи. К.: Наукова думка, 1979. - Т. 20. - С. 173-459.

28. Франко I. Пироги з черницями / I. Франко // Франко I. Зібрання творів у 50-ти т. + додаткові томи. - Т. 16. - К.: Наукова думка, 1978. - С. 201-206.

29. Франко I. Похвала Дрогобича / I. Франко // Франко I. Зібрання творів у 50-ти т. + додаткові томи. - К.: Наукова думка, 1976. - Т. 2. - С. 349-351.

30. Франко І. Рутенці / І. Франко // Франко І. Зібрання творів у 50-ти т. + додаткові томи. - Т. 15. - К.: Наукова думка, 1978. - С. 7-41.

31. Франко I. Сожжение упырей в с. Нагуевичах в 1831г. / І. Франко // Українці: народні вірування, повір'я, демонологія. - К.: Либідь, 1992. - С. 512-526.

32. Франко I. Спомини з моїх гімназійних часів / I. Франко // Франко I. Зібрання творів у 50-ти т. + додаткові томи. - К.: Наукова думка, 1983. - Т. 39. - С. 50-54.

33. Франко I. У столярні. (Із моїх споминів) / І. Франко // Франко I. Зібрання творів у 50-ти т. + додаткові томи. - Т. 21. - К.: Наукова думка, 1979. - С. 171-189.

34. Франко І. Украдене щастя / І. Франко // Франко І. Зібрання творів у 50-ти т. + додаткові томи. - К.: Наукова думка, 1978. - Т. 24. - С. 7-64.

35. Франко I. Українсько-руська студентська мандрівка літом 1884 р. / I. Франко // Франко I. Зібрання творів у 50-ти т. + додаткові томи. - К.: Наукова думка, 1976. - Т. 3. - С. 250-262.

36. Франко I. Як це сталося? / І. Франко // Франко I. Зібрання творів у 50-ти т. + додаткові томи. Т. 34. - К.: Наукова думка, 1981. - С. 372-376. 


\section{REFERENCES}

1. Halyk V. Drohobych v etnohrafichno-folklornii spadshchyni Ivana Franka / V. Halyk // Rozvytok suchasnoi osvity i nauky: rezultaty, problemy, perspektyvy. Tezy II-yi mizhnarodnoi naukovo-praktychnoi konferentsii molodykh vchenykh (Drohobytskyi derzhavnyi pedahohichnyi universytet imeni Ivana Franka, 25 kvitnia 2014 roku) / Redaktory-uporiadnyky: V. Ilnytskyi, A. Dushnyi, I. Zymomria. - Drohobych: Posvit, 2014. - S. 49-51.

2. Horak R. Adresy yunosti Ivana Franka v Drohobychi / R. Horak. - Truskavets: «Frankova krynytsia», $1995-16 \mathrm{~s}$.

3. Horak R. Ivan Franko / Kn. druha. Tsilkom normalna shkola / R. Horak, Ya. Hnativ. - Lviv: Vydavnytstvo ottsiv Vasyliian «Misioner», 2001. - 204 s.

4. Horak R. Ivan Franko / Kn. tretia. Gimnaziia / R. Horak, Ya. Hnativ. - Lviv: Vydavnytstvo ottsiv Vasyliian «Misioner», 2001. $-360 \mathrm{~s}$.

5. Hrytsak Ya. Prorok u svoii vitchyzni. Franko ta yoho spilnota (1856 - 1886) / Ya. Hrytsak. - K.: Krytyka, 2006. $-632 \mathrm{~s}$.

6. Huzar Z. Misto Ivana Franka - Drohobych / Z. Huzar. - Drohobych: vydavets Surma S., 2008. - 192 s.

7. Mnykh R. «Drohobych, Drohobych...» topos Drohobycha u tvorakh I. Franka ta Bruno Shultsa [frahment obrazu Drohobycha u tvorakh Franka] / R. Mnykh // Frankoznavchi studii. - Drohobych, 2005. - S. 64-73.

8. «Tam horod preslavnyi Drohobych lezhyt...» (Vybrani pratsi Ivana Franka pro Drohobych) / Uporiadkuvannia, peredmova i komentari Volodymyra Halyka. - Drohobych: Kolo, 2008. - 200 s.

9. Franko I. «Uhorska kazka» Vatslava Pototskoho i «psia krev» / I. Franko // Franko I. Zibrannia tvoriv u 50-ty t. + dodatkovi tomy. - T. 28. - K.: Naukova dumka, 1980. - S. 305-318.

10. Franko I. Boa constrictor / I. Franko // Zibrannia tvoriv u 50-ty t. + dodatkovi tomy. - T. 14. - K.: Naukova dumka, 1978. - S. 370-443.

11. Franko I. Przyczynek do etnografii ludu ruskiego na Wołyniu / I. Franko // Franko I. Zibrannia tvoriv u 50-ty t. + dodatkovi tomy. - T. 27. - K.: Naukova dumka, 1980. - S. 210-215.

12. Franko I. Batkivshchyna / I. Franko // Franko I. Zibrannia tvoriv u 50-ty t. + dodatkovi tomy. - T. 21. K.: Naukova dumka, 1979. - S. 391-423.

13. Franko I. Boryslav smiietsia / I. Franko // Franko I. Zibrannia tvoriv u 50-ty t. + dodatkovi tomy. T. 15. - K.: Naukova dumka, 1978. - S. 256-480.

14. Franko I. Vandrivka Rusyna z Bidoiu / I. Franko // Franko I. Zibrannia tvoriv u 50-ty t. + dodatkovi tomy. - K.: Naukova dumka, 1979. - T. 1. - S. 126-141.

15. Franko I. Velykyi shum / I. Franko // Franko I. Zibrannia tvoriv u 50-ty t. + dodatkovi tomy. - T. 22. K.: Naukova dumka, 1979. - S. 208-317.

16. Franko I. Gava / I. Franko // Franko I. Zibrannia tvoriv u 50-ty t. + dodatkovi tomy. - T. 18. - K.: Naukova dumka, 1978. - S. 7-31.

17. Franko I. Hirchychne zerno (Iz moikh spomyniv) / I. Franko // Franko I. Zibrannia tvoriv u 50-ty t. + dodatkovi tomy. - K.: Naukova dumka, 1979. - T. 21. - S. 316-332.

18. Franko I. Dalshi bolharski pratsi M. Drahomanova / I. Franko // Franko I. Zibrannia tvoriv u 50-ty t. + dodatkovi tomy. - T. 28. - K.: Naukova dumka, 1980. - S. 293-298.

19. Franko I. Do pytannia pro perekazy pro Mahometa u slovian / I. Franko // Franko I. Zibrannia tvoriv u 50-ty t. + dodatkovi tomy. - T. 29. - K.: Naukova dumka, 1981. - S. 122-148.

20. Franko I. Dobryi zarobok / I. Franko // Franko I. Zibrannia tvoriv u 50-ty t. + dodatkovi tomy. - T. 15. K.: Naukova dumka, 1978. - S. 230-235.

21. Franko I. Drohobytska filantropiia / I. Franko // Franko I. Zibrannia tvoriv u 50-ty t. + dodatkovi tomy. - T. 3. - K.: Naukova dumka, 1976. - S. 248-249.

22. Franko I. Zhydivska viina. Prychynok do porivnialnykh studii nad narodnoiu literaturoiu / I. Franko //

Franko I. Zibrannia tvoriv u 50-ty t. + dodatkovi tomy. - T. 53. - K.: Naukova dumka, 2008. - S. 311-330.

23. Franko I. Zhinocha nevolia v ruskykh pisniakh narodnykh / I. Franko // Franko I. Zibrannia tvoriv u 50-ty t. + dodatkovi tomy. - T. 26. - K.: Naukova dumka, 1980. - S. 210-253.

24. Franko I. Zlisnyi Sydir / I. Franko // Franko I. Zibrannia tvoriv u 50-ty t. + dodatkovi tomy. - T. 16. K.: Naukova dumka, 1978. - S. 433-446.

25. Franko I. Na dni / I. Franko // Zibrannia tvoriv u 50-ty t. + dodatkovi tomy. - T. 15. - K.: Naukova dumka, 1978. - S. 110-163.

26. Franko I. Ostanky pervisnoho svitohliadu v ruskykh i polskykh zahadkakh narodnykh / I. Franko // Franko I. Zibrannia tvoriv u 50-ty t. + dodatkovi tomy. - T. 26. - K.: Naukova dumka, 1980. - S. 332-346.

27. Franko I. Perekhresni stezhky / I. Franko // Franko I. Zibrannia tvoriv u 50-ty t. + dodatkovi tomy. - K.: Naukova dumka, 1979. - T. 20. - S. 173-459. 
28. Franko I. Pyrohy z chernytsiamy / I. Franko // Franko I. Zibrannia tvoriv u 50-ty t. + dodatkovi tomy. T. 16. - K.: Naukova dumka, 1978. - S. 201-206.

29. Franko I. Pokhvala Drohobycha / I. Franko // Franko I. Zibrannia tvoriv u 50-ty t. + dodatkovi tomy. K.: Naukova dumka, 1976. - T. 2. - S. 349-351.

30. Franko I. Rutentsi / I. Franko // Franko I. Zibrannia tvoriv u 50-ty t. + dodatkovi tomy. - T. 15. - K.: Naukova dumka, 1978. - S. 7-41.

31. Franko I. Sozhzhenye upыrei v s. Nahuevychakh v 1831h. / I. Franko // Ukraintsi: narodni viruvannia, poviria, demonolohiia. - K.: Lybid, 1992. - S. 512-526.

32. Franko I. Spomyny z moikh himnaziinykh chasiv / I. Franko // Franko I. Zibrannia tvoriv u 50-ty t. + dodatkovi tomy. - K.: Naukova dumka, 1983. - T. 39. - S. 50-54.

33. Franko I. U stoliarni. (Iz moikh spomyniv) / I. Franko // Franko I. Zibrannia tvoriv u 50-ty t. + dodatkovi tomy. - T. 21. - K.: Naukova dumka, 1979. - S. 171-189.

34. Franko I. Ukradene shchastia / I. Franko // Franko I. Zibrannia tvoriv u 50-ty t. + dodatkovi tomy. - K.: Naukova dumka, 1978. - T. 24. - S. 7-64.

35. Franko I. Ukrainsko-ruska studentska mandrivka litom 1884 r. / I. Franko // Franko I. Zibrannia tvoriv u 50-ty t. + dodatkovi tomy. - K.: Naukova dumka, 1976. - T. 3. - S. 250-262.

36. Franko I. Yak tse stalosia? / I. Franko // Franko I. Zibrannia tvoriv u 50-ty t. + dodatkovi tomy. - T. 34. K.: Naukova dumka, 1981. - S. 372-376.

Стаття надійшла до редакиіï 15.03.2017 p. 